Boston University School of Law

Scholarly Commons at Boston University School of Law

Faculty Scholarship

2002

Bioterrorism, Public Health, and Civil Liberties

George J. Annas

Follow this and additional works at: https://scholarship.law.bu.edu/faculty_scholarship

Part of the Health Law and Policy Commons 
Legal Issues in Medicine

\section{Bioterrorism, Public Health, AND Civil Liberties}

\author{
George J. Annas, J.D., M.P.H.
}

$\mathrm{T}$ HE prospect of having to deal with a bioterrorist attack, especially one involving smallpox, has local, state, and federal officials rightly concerned. ${ }^{1,2}$ Before September 11, most procedures for dealing with a bioterrorist attack against the United States were based on fiction. Former President Bill Clinton became engaged in the bioterrorism issue in 1997, after reading Richard Preston's novel The Cobra Event. ${ }^{3}$ In Tom Clancy's 1996 Executive Orders, ${ }^{4}$ the United States is attacked by terrorists using a strain of Ebola virus that is transmissible through the air. To contain the epidemic, the President declares a state of emergency, orders that all nonessential businesses and places of public assembly be closed, and suspends all interstate travel by airplane, train, bus, and automobile. In defending the order, the fictional President makes a statement that is now often used to justify major changes in our criminal laws: "The Constitution is not a suicide pact." 4

The anthrax attacks through the U.S. mail demonstrated that the federal government must provide better planning, coordination, and communication with the public, as well as better drugs and vaccines. ${ }^{5,6}$ What remains more controversial is whether we must give up any civil liberties to deal with this "different kind of war." What steps should the government take to prepare for a bioterrorist attack involving the use of smallpox or another contagious agent, and which level of government, state or federal, should take the lead?

\section{BIOTERRORISM AND PUBLIC HEALTH}

The prospect of a bioterrorist attack and the actual attacks in Florida, the District of Columbia, New York, New Jersey, and Connecticut have changed public health in the United States. Since the founding of the country, public health has been considered primarily the business of the states. The reason is that when the former colonies delegated powers to the federal government in the U.S. Constitution, they retained the authority to protect the public's health

From the Health Law Department, Boston University School of Medicine, Boston. and safety, usually referred to as the state's "police powers." 7,8 The federal government may, nonetheless, affect public health and safety through its constitutional authority to spend money, regulate interstate and foreign commerce, and provide for national defense. The Congress established the Public Health Service and the Centers for Disease Control and Prevention (CDC) with federal money and used its authority under the commerce clause of the Constitution to establish the Food and Drug Administration (FDA). The creation of these federal agencies, however, did not alter the states' responsibility for public health; the anthrax attacks did.

Bioterrorism - the deliberate release of a harmful biologic agent to intimidate civilians and their government - constitutes a threat to public health that differs from any other public health threat that our country has faced. An act of bioterrorism is both a state and a federal crime, and it can also be an act of war. ${ }^{9}$ Because of our highly developed transportation system, communicable diseases can be spread widely in a short period of time. All these factors make it reasonable to view bioterrorism as an inherently federal matter under both the national-defense and commerce clauses of the Constitution. Thus, the Federal Bureau of Investigation (FBI) and the CDC took the lead in investigating all the anthrax mail attacks. Moreover, had the attacks originated outside the country, the U.S. military and the Central Intelligence Agency would have been called on to respond.

\section{BUILDING A MODERN PUBLIC HEALTH SYSTEM}

In the immediate aftermath of the September 11 attacks and the subsequent anthrax attacks through the U.S. mail, hospitals, cities, states, and federal officials began developing or revisiting protocols to deal with possible biologic attacks in the future. The federal response has so far emphasized the stockpiling of drugs and vaccines that could be used to respond to an attack, especially one involving smallpox. ${ }^{10}$ Other proposals have included improving the public health infrastructure of the country (especially the ability to monitor diagnoses made in emergency departments and pharmacy sales of relevant drugs) and training emergency medical personnel to recognize and treat the diseases most likely to be caused by a bioterrorist attack (such as anthrax, smallpox, and plague). ${ }^{11}$ Major efforts are also under way to improve coordination and communication among local, state, and federal officials who are responsible for responding to emergencies and to delineate more clearly the lines of authority involving "homeland security." All these measures are reasonable and responsible steps our government should take.

Properly worried that many state public health 
laws are outdated and perhaps inadequate to permit state officials to contain an epidemic caused by a bioterrorist attack, the CDC has advised all states to review the adequacy of their laws, with special attention to provisions for quarantining people in the event of a smallpox attack. ${ }^{12}$ In addition, the CDC released a proposed model act for the states, the Model State Emergency Health Powers Act, on October 23, 2001.12,13 The act was constructed by the Center for Law and the Public's Health at Georgetown University and Johns Hopkins University and was pieced together from a variety of existing state laws.

\section{THE ORIGINAL MODEL STATE EMERGENCY HEALTH POWERS ACT}

The original model act permits the governor to declare a "state of public health emergency," and this declaration, in turn, gives state public health officials the authority to take over all health care facilities in the state, order physicians to act in certain ways, and order citizens to submit to examinations and treatment, with those who refuse to do so subject to quarantine or criminal punishment. The model act specifies that public health officials and those working under their authority are immune from liability for their actions, including actions that cause permanent injury or death; the only exceptions are in cases of gross negligence and willful misconduct. A public health emergency (the condition that requires the governor to declare a state of public health emergency) is defined as "an occurrence or imminent threat of an illness or health condition, caused by bioterrorism, epidemic or pandemic disease, or [a] novel and highly fatal infectious agent or biological toxin, that poses a substantial risk of a significant number of human fatalities or incidents of permanent or long-term disability."13

The declaration of a state of public health emergency permits the governor to suspend state regulations, change the functions of state agencies, and mobilize the militia. Under the model act, all public health personnel will be issued special identification badges, to be worn "in plain view," that "shall indicate the authority of the bearer to exercise public health functions and emergency powers. . . ."13 Public health personnel may "compel a health care facility to provide services or the use of its facility if such services or use are reasonable and necessary for emergency response... [including] transferring the management and supervision of the health care facility to the public health authority."

According to the act's provisions, public health personnel have exceptionally broad powers, and failure of physicians and citizens to follow their orders is a crime. Section 502 of the act, which covers mandatory medical examinations and testing, states:
Any person refusing to submit to the medical examination and/or testing is liable for a misdemeanor. If the public health authority is uncertain whether a person who refuses to undergo medical examination and/or testing may have been exposed to an infectious disease or otherwise poses a danger to public health, the public health authority may subject the individual to isolation or quarantine. . . . Any [health care provider] refusing to perform a medical examination or test as authorized herein shall be liable for a misdemeanor. . . . An order of the public health authority given to effectuate the purposes of this subsection shall be immediately enforceable by any peace officer. ${ }^{13}$

Section 504, on vaccination and treatment, states, "Individuals refusing to be vaccinated or treated shall be liable for a misdemeanor. If, by reason of refusal of vaccination or treatment, the person poses a danger to the public health, he or she may be subject to isolation or quarantine. . . . An order of the public health authority given to effectuate the purposes of this Section shall be immediately enforceable by any peace officer." 13

\section{THE NEED FOR NEW STATE LAWS ON BIOTERRORISM}

Of course, state public health, police, fire, and emergency planners should be clear about their authority, and to the extent that it encourages states to review their emergency laws, the model act is constructive. On the other hand, many of the provisions of this act, especially those giving public health officials authority over physicians and hospitals, as well as authority to enforce a quarantine in the absence of meaningful standards, seem to be based on the assumption that neither physicians nor citizens are likely to cooperate with public health officials in the event of a bioterrorist attack. This assumption, in turn, seems to be based on the results of theoretical planning exercises involving simulated bioterrorist attacks, including the Top Officials 2000 (Top Off) and Dark Winter exercises. ${ }^{12}$ Top Off was an exercise that simulated a bioterrorist attack on Denver that involved the use of aerosolized Yersinia pestis, the bacteria that causes plague. ${ }^{14}$ Dark Winter simulated a smallpox attack on Oklahoma City. ${ }^{15}$ Using these simulated cases as a basis for legislation is unreasonable, given the extremely high level of voluntary cooperation on the part of the public, physicians, and hospitals after both the September 11 terrorist attacks and the subsequent anthrax attacks.

In my opinion, the model act poses several problems. First, proposed laws should respond to real problems. It is not at all clear what problem the model act is intended to solve, and this makes it extremely difficult to evaluate.

Second, the authority to respond to a bioterrorist attack or a new epidemic that the model act provides 
is much too broad, since it applies not just to real emergencies such as a smallpox attack but also to nonemergency conditions as diverse as annual influenza epidemics and the AIDS epidemic. ${ }^{16,17}$

Third, although it may make sense to put public health officials in charge of responding to a smallpox attack, it may not make sense to put them in charge of responding to every type of bioterrorist event. In the event of a bioterrorist attack, the state public health department has a major role in limiting the public's exposure to the agent. However, the tasks of identifying affected persons, reporting them, treating them, and taking preventive actions will be performed by physicians, nurses, emergency medical personnel, and hospitals. The primary role of public health authorities will usually be, as it was in the wake of the anthrax attacks, to provide guidance to the public and other government officials in identifying and dealing with the disease and to provide laboratory facilities where exposure can be evaluated and diagnoses definitively established. ${ }^{5,6,18}$

Fourth, there is no evidence from either the September 11 attacks or the anthrax attacks that physicians, nurses, or members of the public are reluctant to cooperate in the response to a bioterrorist attack or are reluctant to take drugs or vaccines recommended by public health or medical officials. In fact, medical personnel in the affected areas volunteered their time and expertise to help victims of the September 11 attacks, and the public lined up to be tested for anthrax and stockpiled ciprofloxacin. ${ }^{19}$ The public demand for testing and treatment was so great that the CDC had to issue recommendations against both.

Of course, anthrax, unlike smallpox, is not spread from person to person. The situation might have been different if smallpox had been used as a biologic weapon or if thousands or tens of thousands of people had been infected with anthrax. Nonetheless, there is no empirical evidence that draconian provisions for quarantine, such as those outlined in the model act, are necessary or desirable. Persons with smallpox, for example, are most infectious only after fever and a rash have developed, ${ }^{12}$ and then they are usually so sick that they are likely to accept whatever care is available. Moreover, according to Barbera et al., the "long incubation period (10-17 days) almost ensures that some persons who are infected in the [smallpox] attack will have traveled great distances from the site of the exposure before the disease is recognized or quarantine could be implemented." 14 The key to an effective public health response is identifying and helping those who have been exposed. Even with a sufficient supply of smallpox vaccine, a quarantine enforced by the police would probably not be effective in controlling an outbreak of smallpox..$^{12,14,20}$
This is a major reason for the current recommendation that smallpox vaccine be made available to the public on a voluntary basis. ${ }^{21}$

Finally, even if it is concluded that a quarantine law may be useful to respond to a bioterrorist attack (e.g., as a means of ensuring that the few unwilling Americans, if any, would be treated, vaccinated, or quarantined), it should be a federal law, not a state law. The reason is that bioterrorism is a matter of national security, not just of state police powers. The existing federal quarantine law is based on the commerce clause of the Constitution (with special provisions for cholera, plague, smallpox, typhus, and yellow fever), and Congress could examine and update it to deal with bioterrorism. ${ }^{22,23}$ The governors of the states involved in the anthrax attacks all realized that bioterrorism is fundamentally a federal issue and quickly called for action from both the FBI and the CDC to deal with the attacks.

\section{CIVIL LIBERTIES AND PUBLIC HEALTH EMERGENCIES}

The model act is based on the belief that in public health emergencies, there must be a trade-off between the protection of civil rights and effective public health interventions. There is, of course, precedent for this belief, and the preamble to the model act cites the 1905 case of Jacobson v. Massachusetts in stating the proposition that "the whole people covenants with each citizen, and each citizen with the whole people, that all shall be governed by certain laws for the "common good." ", ,13 Jacobson v. Massachusetts involved a state statute that permitted local boards of health to require vaccination when they deemed it "necessary for the public health or safety." There were no provisions for quarantine in the statute, and refusal to be vaccinated was punishable by a $\$ 5$ fine. Refusal was anticipated in the early 1900s because vaccination itself was controversial, there were no antibiotics, physicians were not widely trusted, science and medicine were in their infancy, and hospitals were primarily "pesthouses." 24 Trade-offs between civil liberties (the right to refuse treatment) and public health interventions (mandatory vaccination) seemed necessary in such circumstances. ${ }^{25}$

In Jacobson v. Massachusetts, the Supreme Court cited the military draft as the precedent for upholding the Massachusetts law. The point is not that the Constitution does not give the government wide latitude to respond in times of war and public health emergencies - it does. The point is that trade-offs between civil rights and public health measures are not always required and can be counterproductive. Just as we have been able to abolish the draft and rely on all-volunteer armed forces, so it seems reasonable to think that we can rely on Americans to 
follow the reasonable instructions of government officials for their own protection.

Today, almost 100 years after Jacobson, both medicine and constitutional law are radically different. ${ }^{7}$ We now take constitutional rights much more seriously, including the right of a competent adult to refuse any medical treatment, even life-saving treatment. ${ }^{26}$ Of course, we would still permit public health officials to quarantine persons with a serious communicable disease, such as infectious tuberculosis, but only if they could not or would not accept treatment and thus put others at risk for exposure. ${ }^{27}$ Even then, however, we would require public officials to use the "least restrictive alternative" and resort to quarantine only after other interventions, such as directly observed therapy, had failed. ${ }^{27}$ Pro- $^{-}$ visions for quarantine are also accompanied by dueprocess rights, including the right to legal representation and the right to a hearing. ${ }^{27}$

The model act seems to have been drafted for a different age; it is more appropriate for the United States of the 19th century than for the United States of the 21 st century. Today, all adults have the constitutional right to refuse examination and treatment, and such a refusal should not result in involuntary confinement simply on the whim of a public health official. At the very least, persons suspected of having a contagious disease should have the option of being examined by physicians of their own choice and, if isolation is necessary, of being isolated in their own homes. ${ }^{27}$ The requirement that physicians treat patients against their will and against the physicians' medical judgment under penalty of criminal law has no precedent and makes no sense. Moreover, state governors already have broad emergency powers; there is no compelling reason to expand them.

Just as important as the constitutional questions posed by the model act is the pragmatic question of whether it is likely to undermine the public's trust in public health - trust that is absolutely essential for containing panic in a bioterrorist-induced epidemic. Unlike the situation at the turn of the last century, for example, we have televised news 24 hours a day, cell phones, and automobiles, making a large-scale quarantine impossible unless the public believes that it is absolutely necessary to prevent the spread of fatal disease and is fairly and safely administered. Enactment of a law that made it a crime to disobey a public health officer would rightly engender distrust, because it would suggest that public officials could not provide valid reasons for their actions.

The necessity of maintaining the public's trust also means that the argument that, in a public health emergency, there must be a trade-off between effective public health measures and civil rights is simply wrong. As the AIDS epidemic has demonstrated, the promotion of human rights can be essential for dealing effectively with an epidemic. ${ }^{28}$ Early in the course of the AIDS epidemic, public health officials recognized that mandatory screening for human immunodeficiency virus would simply help drive the epidemic underground, where it would spread faster and wider. Likewise, draconian quarantine measures would probably have the unintended effect of encouraging people to avoid public health officials and physicians rather than to seek them out. In this regard, the protection of civil liberties is a core ingredient in a successful response to a bioterrorist attack. Provisions that treat citizens as the enemy, with the use of the police for enforcement, are much more likely to cost lives than to save them. This is one reason why there has not been a large-scale quarantine in the United States for more than 80 years and why experts on bioterrorism doubt that such a quarantine would be effective. ${ }^{14,20}$

\section{THE REVISED MODEL ACT}

On December 21, 2001, in response to criticisms of the model act, including those I have summarized, a revised version was released. ${ }^{29}$ No one any longer considers the act a "model." Instead, it is now labeled a "draft for discussion." The new version does "not represent the official policy, endorsement, or views" of anyone, including the authors themselves and the CDC. ${ }^{29}$

Although the revised act can be viewed as a modest improvement, all the fundamental problems remain. Failure to comply with the orders of public health officials for examination or treatment is no longer a crime but results in isolation or quarantine. Criminal penalties continue to apply to failure to follow isolation or quarantine "rules" that will be written at a future time. Physicians and other health care providers can still be required "to assist" public health officials, but cooperation is now coerced as "a condition of licensure" instead of a legal requirement with criminal penalties for noncompliance. The quarantine provisions have been improved, with a new requirement that quarantine or isolation be imposed by "the least restrictive means necessary" and stronger due-process protection, including hearings and legal representation for those actually quarantined. ${ }^{29}$ Nonetheless, on the basis of a written directive by a public health official, a person can still be quarantined for 15 days before a hearing must be held, and the hearing itself can be for groups of quarantined persons rather than individuals. ${ }^{29}$

Some of the revised quarantine provisions seem even more arbitrary. A major criticism of the original version of the act was the extreme vagueness of its standard for quarantine, which invited the arbitrary use of force. According to the original version, 
quarantine can be ordered if a public health official is "uncertain whether a person who refuses to undergo medical examination or testing may have been exposed to an infectious disease or otherwise poses a danger to public health." In the revised version, the standard is even vaguer. Quarantine can be ordered when the person's refusal to be examined or tested "results in uncertainty regarding whether he or she has been exposed to or is infected with a contagious or possibly contagious disease or otherwise poses a danger to public health." 29 This is no standard at all; it simply permits public health authorities to quarantine anyone who refuses to be examined or treated, for whatever reason, since all refusals will result in uncertainty. If one were already certain, one would not order the test. At the hearing, if requested, the standard for a continued quarantine appears to be the finding that the person would "significantly jeopardize the public health authority's ability to prevent or limit the transmission of a contagious or possibly contagious disease to others." This standard also makes no sense because the public health focus, I think, should be on the person's condition and on the determination of whether it poses a danger to others, not on the public health authority's ability to function.

These vague standards are especially troublesome because the act's incredible immunity provision remains unchanged. Thus, all state public health officials and all private companies and persons operating under their authority are granted immunity from liability for their actions (except for gross negligence or willful misconduct), even in the case of death or permanent injury. Out-of-state emergency health care providers have even greater protection; they are given immunity from liability for everything but manslaughter. In my opinion, such immunity is something public health authorities should not want (even though it may have superficial appeal), because it means that they are not accountable for their actions, no matter how arbitrary. The immunity provision thus serves only to undermine the public's trust in public health authorities. Citizens should never be treated against their will by their government, but if they ever are, they should be fully compensated for injuries suffered as a result.

\section{CONCLUSIONS}

All sorts of proposals were floated in the wake of the September 11 attacks - some potentially useful, such as irradiation of mail at the facilities that had been targeted, and some potentially dangerous, such as the use of secret military tribunals and measures that would erode lawyer-client confidentiality, undermine our constitutional values, and make us less able to criticize authoritarian countries for similar behavior. I think the Model State Emergency Health Powers Act is one of the dangerous proposals.

Bioterrorism is primarily a federal, not a state, issue, and actions undertaken to prevent and respond to bioterrorism should be a federal priority. ${ }^{30}$ Laws that provide funding for training in the recognition and treatment of diseases caused by pathogens that could be used as biologic weapons deserve support, as do laws that improve communication and coordination in response to such an attack. The Biological and Toxin Weapons Convention also deserves our support. ${ }^{31}$ In my opinion, laws that treat Americans and their physicians as the enemy and grant broad, arbitrary powers to public health officials without making them accountable do not deserve support and distract us from important work that needs to be done. The fear and frenzy that prompted state legislatures to consider new antiterrorist laws after September 11 seem to have abated, and reason may yet prevail over panic. ${ }^{32}$ Of course the Constitution is not a suicide pact, but we do not have to sacrifice civil liberties for an effective public health response to a bioterrorist attack.

\section{REFERENCES}

1. Tucker JB. Scourge: the once and future threat of smallpox. New York: Atlantic Monthly Press, 2001.

2. Gillis J, Connolly C. U.S. details response to smallpox: cities could be quarantined and public events banned. Washington Post. November 27, 2001:Al.

3. Preston R. The cobra event. New York: Random House, 1997.

4. Clancy T. Executive orders. New York: G.P. Putnam, 1996.

5. Lipton E, Johnson K. Tracking bioterror's tangled course. New York Times. December 26, 2001:Al.

6. Altman LK, Kolata G. Anthrax missteps offer guide to fight next bioterror battle. New York Times. January 6, 2002(Section 1):1.

7. Wing KR. The law and the public's health. 5th ed. Chicago: Health Administration Press, 1999.

8. Jacobson v. Massachusetts, 197 U.S. 11 (1905).

9. Fidler DP. The malevolent use of microbes and the rule of law: legal challenges presented by bioterrorism. Clin Infect Dis 2001;33:686-9. 10. Stolberg SG. Health secretary testifies about germ warfare defenses. New York Times. October 4, 2001:B7.

11. Miller J, Engelberg S, Broad W. Germs: biological weapons and America's secret war. New York: Simon \& Schuster, 2001.

12. Interim smallpox response plan and guidelines, for distribution to state and local public health bioterrorism response planners, November 21 ,

2001 draft. Guide C: isolation and quarantine guidelines. Atlanta: Centers for Disease Control and Prevention, 2001.

13. The Model State Emergency Health Powers Act: as of October 23, 2001. Atlanta: Centers for Disease Control and Prevention, 2001. (Accessed April 5, 2002, at http://www.publichealthlaw.net/MSEHPA/ MSEHPA.pdf.)

14. Barbera J, Macintyre A, Gostin L, et al. Large-scale quarantine following biological terrorism in the United States: scientific examination, logistic and legal limits, and possible consequences. JAMA 2001;286:2711-7.

15. Marlands L. Bioterror: all the rules change. Christian Science Monitor. December 17, 2001:1.

16. Mariner W. Bioterrorism act: the wrong response. National Law Journal. December 17, 2001:18.

17. Parmet WE, Mariner WK. A health act that jeopardizes public health. Boston Globe. December 1, 2001:A15

18. Stolberg SG, Miller J. Bioterror role an uneasy fit for the C.D.C. New York Times. November 11, 2001:Al.

19. Martinez B, Harris G. Anxious patients plead with doctors for antibiotics. Wall Street Journal. October 15, 2001:B1.

20. Osterholm MT, Schwartz J. Living terrors: what America needs to know to survive the coming bio-terrorist catastrophe. New York: Delacorte Press, 2000. 
21. Bicknell WJ. The case for voluntary smallpox vaccination. $\mathrm{N}$ Engl J Med 2002;346:1323-5.

22. Public Health Service Act, as amended, 42 U.S.C. 264 (1983).

23. Quarantine, inspection, licensing: interstate quarantine, 42 C.F.R. 70.1-8 (2000)

24. Rosenberg CE. The care of strangers: the rise of America's hospital system. New York: Basic Books, 1987.

25. Albert MR, Ostheimer KG, Breman JG. The last smallpox epidemic in Boston and the vaccination controversy, 1901-1903. N Engl J Med 2001;344:375-9

26. Annas GJ. The bell tolls for a constitutional right to physician-assisted suicide. N Engl J Med 1997;337:1098-103.

27. Idem. Control of tuberculosis: the law and the public's health. N Eng J Med 1993;328:585-8.

28. Mann JM, Gostin L, Gruskin S, Brennan T, Lazzarini Z, Fineberg

HV. Health and human rights. Health Hum Rights 1994;1:6-23.
29. The Model State Emergency Health Powers Act: as of December 21 2001. Atlanta: Centers for Disease Control and Prevention, 2001. (Accessed April 5, 2002, at http://www.publichealthlaw.net/MSEHPA/

MSEHPA2.pdf.

30. Kellman B. Biological terrorism: legal measures for preventing a catastrophe. Harv J Law Public Policy 2001;24:417-85.

31. Scharf MP. Clear and present danger: enforcing the international ban on biological and chemical weapons through sanctions, use of force, and criminalization. Mich J Int Law 1999;20:477-521.

32. Gavin R. Frenzy to adopt terrorism laws starts to recede. Wall Street Journal. March 27, 2002:B1.

Copyright (C) 2002 Massachusetts Medical Society.

\section{FULL TEXT OF ALL JOURNAL ARTICLES ON THE WORLD WIDE WEB}

Access to the complete text of the Journal on the Internet is free to all subscribers. To use this Web site, subscribers should go to the Journal's home page (http://www.nejm.org) and register by entering their names and subscriber numbers as they appear on their mailing labels. After this one-time registration, subscribers can use their passwords to log on for electronic access to the entire Journal from any computer that is connected to the Internet. Features include a library of all issues since January 1993 and abstracts since January 1975, a full-text search capacity, and a personal archive for saving articles and search results of interest. All articles can be printed in a format that is virtually identical to that of the typeset pages. Beginning six months after publication the full text of all original articles and special articles is available free to nonsubscribers who have completed a brief registration.

1342 • N Engl J Med, Vol. 346, No. 17 • April 25, $2002 \cdot$ www.nejm.org 